Original article

\section{Geographical distribution of Leishmania species in Colombia, 1985-2017}

\author{
Jussep Salgado-Almario, Carlos Arturo Hernández², Clemencia Ovalle-Bracho \\ ${ }^{1}$ Hospital Universitario Centro Dermatológico Federico Lleras Acosta, Bogotá, D.C., Colombia \\ 2 Instituto Nacional de Salud, Bogotá, D.C., Colombia
}

Introduction: Knowledge of the geographical distribution of Leishmania species allows guiding the sampling to little-studied areas and implementing strategies to define risk zones and priority areas for control.

Objective: Given that there is no publication that collects this information, the search, review, and compilation of the available scientific literature that has identified species in Colombia is presented in this paper.

Materials and methods: A bibliographic search was performed in PubMed, Web of Knowledge, Google Scholar, SciELO and LILACS with the terms "(Leishmania OR Leishmaniasis) AND species AND Colombia”, without restrictions on publication year, language or infected organism; records of national scientific events and repositories of theses from Colombian universities were also included.

Results: Eighty-six scientific documents published between 1985 and 2017 were found in which the species of Leishmania and their geographical origin were indicated. The species reported, in descending order of frequency, were: Leishmania (Viannia) panamensis, $L$. (V.) braziliensis, L. (V.) guyanensis, L. (Leishmania) infantum, L. (L.) amazonensis, L. (L.) mexicana, $L$. (V.) colombiensis, $L$. (V.) lainsoni and $L$. (V.) equatorensis; the last three were found with the same frequency. Leishmania species were reported from 29 departments. Conclusion: Information on the distribution of Leishmania species in Colombia is limited; therefore, it is necessary to gather existing data and propose studies that consolidate the distribution maps of Leishmania species in Colombia. This would allow the detection of areas where species have not been identified as well as the comparison of existing parasite and vector distributions.

Keywords: Leishmania; leishmaniasis/epidemiology; geographic mapping; vectors diseases; reservoirs; Colombia.

Distribución geográfica de las especies de Leishmania en Colombia, 1985-2017

Introducción. El conocimiento de la distribución geográfica de las especies de Leishmania permite orientar el muestreo hacia áreas poco estudiadas e implementar estrategias para detectar zonas de riesgo y áreas prioritarias de control.

Objetivo. Dado que no existe una publicación que reúna esta información, se planteó la revisión y compilación de la literatura científica disponible de estudios de identificación de especies del país.

Materiales y métodos. Se llevó a cabo una búsqueda bibliográfica en PubMed, Web of Knowledge, Google Académico, SciELO y Lilacs con los términos "(Leishmania OR Leishmaniasis) AND especie AND Colombia", así como en memorias de eventos científicos nacionales y repositorios de tesis y trabajos de grado de universidades del país.

Resultados. Se encontraron 86 documentos científicos publicados entre 1985 y 2017, en los cuales se informaron la especie de Leishmania y el origen geográfico. Las especies circulantes reportadas, en su orden de frecuencia, fueron: Leishmania (Viannia) panamensis, L. (V.) braziliensis, L. (V.) guyanensis, L. (Leishmania) infantum, L. (L.) amazonensis, L. (L.) mexicana, L. (V.) colombiensis, L. (V.) lainsoni y $L$. (V.) equatorensis, las últimas tres, con igual frecuencia. Los reportes proceden de 29 departamentos. Conclusión. La información de la distribución de las especies de Leishmania en Colombia es limitada. Por lo tanto, se necesita reunir los datos existentes y plantear trabajos que permitan consolidar el mapa de distribución de las especies en el país, lo cual permitiría detectar las zonas sin información de las especies circulantes y establecer la concordancia entre su distribución y la de los vectores.

Palabras clave: Leishmania; leishmaniasis/epidemiología; mapeo geográfico; vectores de enfermedades; reservorios; Colombia.

Leishmaniasis is a parasitic disease caused by flagellated protozoa of the genus Leishmania which are transmitted by the bite of female phlebotomine sand flies and can give rise to any of the three main clinical forms in the human host: Cutaneous, mucosal or visceral. 
According to data from the World Health Organization (WHO), there have been cases reported in 102 countries, with an annual estimate of 0.2 to 0.4 million cases of visceral leishmaniasis, and 0.7 to 1.2 million of cutaneous leishmaniasis (1). With the exception of the islands of San Andrés and Providencia, leishmaniases are diseases endemic to Colombia, with 10,743 confirmed cases in 2016. Of these, 10,561 corresponded to the cutaneous form, 122 to the mucosal form, and 60 to the visceral form (2). As such, Colombia is among the top ten countries with the highest incidence of cutaneous leishmaniasis in the world, where $60 \%$ of the population is at risk of acquiring this clinical form (3).

In Colombia, five studies have been conducted to establish the geographical distribution of Leishmania spp. (4-8). The identification of species was made from parasites isolated from patients, sand flies, and animal hosts. Geographical distribution maps were drawn that indicated the origin of the patient or the infected organism. However, these studies achieved only partial coverage of the different areas of the country and the distribution of circulating species is still largely unknown in many parts of Colombia. Other smaller-scale studies, which reported disease outbreaks through active case finding or the capture of sand flies as well as potential reservoirs, have filled in some gaps regarding the presence of Leishmania spp. in other geographical zones (9-13).

Currently, there is no publication that compiles the reports of species in Colombia; for this reason, this work aimed to search, review, and compile the available scientific literature regarding Leishmania spp. and their geographical distribution in Colombia.

\section{Materials and methods}

\section{Search strategy and selection criteria}

A bibliographic search was carried out in PubMed, Web of Knowledge, Google Academic, SciELO and LILACS databases in order to collect all available information related to the identification of Leishmania species in Colombia. The search was made with the combination of the boolean terms "(Leishmania OR Leishmaniasis) AND species AND Colombia", without restrictions on the year of publication, language or infected organism. In addition, the records of national scientific events (among them those of eleven Colombian Congresses of Tropical Medicine from 1987 to 2015) and repositories of theses from Colombian universities were searched.

The identification of parasites to the genus level, the geographical origin of the patient, and the vector or the infected reservoir were used as inclusion criteria.

\section{Extraction and synthesis of information}

For this review, all available scientific literature that met the inclusion criteria was taken into account; however, given the large number of documents, only published articles and gray literature with unique reports in the country were included.

Once the search results were compiled, the duplicate articles were identified and eliminated. Subsequently, those in which the title and summary were not related to the topic of interest were excluded. The full text of the articles, abstracts, and theses was reviewed to identify those that met the inclusion criteria. 
During the review of each document, the following data were extracted: The geographical origin of the sample, the host (human, vector or reservoir), the clinical form of the disease, the typing method used, and the species or subgenus identified.

\section{Results}

There were 86 articles published between 1985 and 2017 in which the species of the Leishmania spp. and the geographical origin of the sample were indicated. Of these, 57 were scientific articles and 29 corresponded to gray literature, of which 26 were abstracts presented at national scientific events and 3 were undergraduate degree theses.

\section{Geographical distribution}

Studies of the geographical distribution of Leishmania spp. report, in order of their frequency, the circulation of Leishmania (Viannia) panamensis, L. (V.) braziliensis, L. (V.) guyanensis, L. (Leishmania) infantum, L. (L.) amazonensis, $L$. (L.) mexicana, $L$. (V.) colombiensis, $L$. (V.) lainsoni, and $L$. $(V$.$) equatorensis; the last three with equal frequency (4-8).$

According to the studies by Corredor, et al. (4), Ovalle, et al. (5), and Ramírez, et al. (6), in which the distribution of species by department is described, L. (V.) panamensis, L. (V.) braziliensis, L. (L.) mexicana and $L$. (L.) infantum are, in order, the species with the greatest geographical distribution and are present in 22, 19, 12 and 8 departments of the country, respectively. These studies provide an approximation of the distribution of Leishmania spp. in Colombia; however, they do not represent the entire country.

It is worth noting that some species grow better in cultures than others. Given this fact, when comparing $L$. ( $V$.) panamensis and $L$. $(V$.) braziliensis frequencies, caution must be exercised in claiming that one species' geographical distribution is greater or lesser than that of other species.

To determine the distribution of Leishmania spp. by department, we compiled information of the identified species and the geographical origin of the organism based on the 86 works that were found in the bibliographical review. Information on geographical origin was variable; some studies included detailed information, including the municipality, the county (vereda) or both, and others included less detailed information, such as department, natural region or river basins. The geographical scale depended primarily on the study coverage; studies of cases and outbreaks of leishmaniasis provided the most detailed information.

We also describe the geographical distribution of the Leishmania species reported in Colombia (4-42). However, given the small number of studies with detailed information on geographical origin, we decided to characterize the distribution by department (table 1 and figure 1 ).

Leishmania (V.) panamensis was identified in 39 of the 86 included studies. It was reported in 26 of the 32 Colombian departments. The departments with the highest number of reports of this species are, in order of frequency, Chocó (15/39), Antioquia (14/39), and Valle del Cauca (11/39), which are located in the western part of the country. According to the studies that included detailed information on the origin of the patients, $L$. $(V$.) panamensis was identified in 52 municipalities of 12 departments of Colombia. Of these municipalities, 28 belong to the department of Antioquia. There are no reports of this species in the departments of Amazonas, Atlántico, Cesar, La Guajira, and Quindío. 
Table 1. Leishmania species reported in Colombia for each department

\begin{tabular}{|c|c|c|c|c|c|c|c|c|c|}
\hline \multirow{2}{*}{ Department } & \multicolumn{9}{|c|}{ Leishmania species } \\
\hline & Lp & Lb & Lm & Lg & Li & La & Lco & Leq & Lla \\
\hline Amazonas & & & & $x$ & & & & & \\
\hline Antioquia & $x$ & $x$ & $x$ & $x$ & & $x$ & $x$ & $x$ & $x$ \\
\hline Arauca & $x$ & & & & & & & & \\
\hline Bolívar & $x$ & $x$ & & & $x$ & & & & \\
\hline Boyacá & $x$ & $x$ & & $x$ & $x$ & $x$ & & & \\
\hline Caldas & $\mathrm{x}$ & $x$ & $x$ & & $x$ & & & & \\
\hline Caquetá & $x$ & $x$ & $x$ & $x$ & & & & & \\
\hline Casanare & $x$ & $x$ & $x$ & & & & & & \\
\hline Cauca & $x$ & $x$ & $x$ & & & & & & \\
\hline Cesar & & $x$ & & & & & & & \\
\hline Chocó & $x$ & $x$ & & & & $x$ & & & \\
\hline Córdoba & $x$ & $x$ & & & $x$ & & & & \\
\hline Cundinamarca & $x$ & $x$ & $x$ & & $x$ & & & & \\
\hline Guainía & $x$ & $x$ & & & & & & & \\
\hline Guaviare & $x$ & $x$ & $x$ & $x$ & & & & & \\
\hline Huila & $x$ & $x$ & & & $x$ & & & & \\
\hline La Guajira & & $x$ & & $x$ & $x$ & & & & \\
\hline Magdalena & $x$ & $x$ & & & & & & & \\
\hline Meta & $x$ & $x$ & $x$ & $x$ & $x$ & $x$ & & & \\
\hline
\end{tabular}

Lp: L. (V.) panamensis; Lb: L. (V.) braziliensis; Lm: L. (L.) mexicana; Lg: L. (V.) guyanensis; Li: L. (L.) infantum; La: L. (L.) amazonensis; Lco: L. (V.) colombiensis; Leq: (L. (V.) equatorensis; Lla: L. (V.) lainsoni

Figure 1. Geographical distribution by department of Leishmania species reported in Colombia, 1985-2017
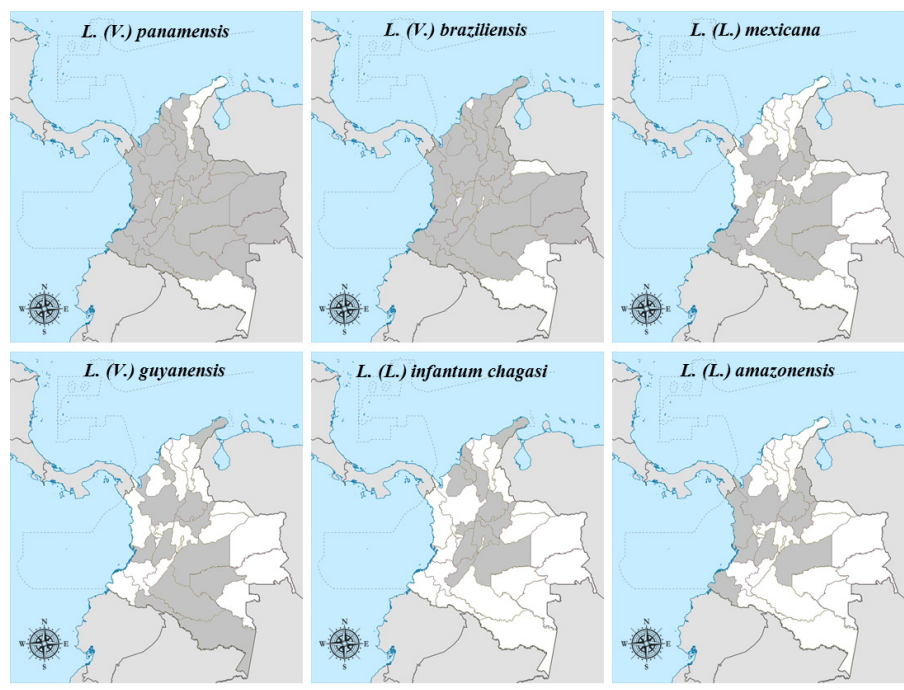

L. (L.) infantum chagasi
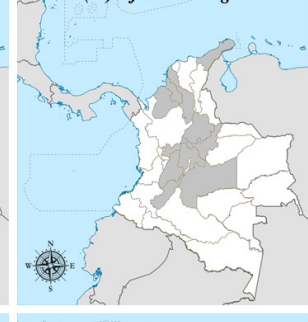

L. (L.) amazonensis
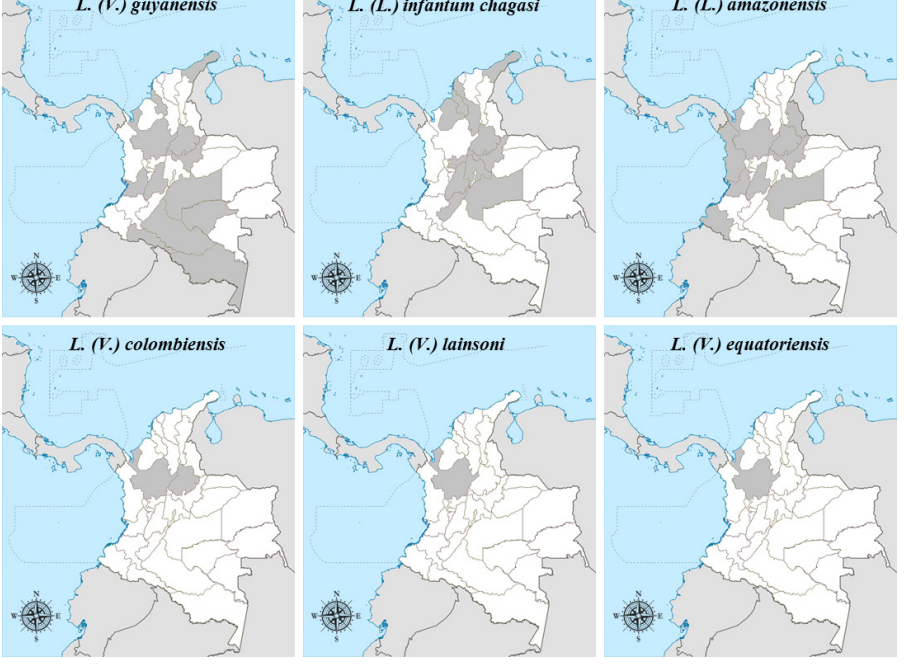
Leishmania ( $V$.) braziliensis was reported in organisms from 26 departments. According to the 26 studies in which it was identified, the departments with the highest number of reports of this species are Meta (10/26), Cundinamarca (6/26) and Caquetá (6/26). At the municipality level, L. (V.) braziliensis was reported in 12 municipalities in the departments of Antioquia, Bolívar, Boyacá, Cauca, Nariño, Norte de Santander, Sucre, Tolima, and Valle del Cauca. The departments without reports of this species are Amazonas, Atlántico, Arauca, Guainía, Quindío, and San Andrés and Providencia.

According to the 8 studies in which $L$. (L.) mexicana was identified, the circulation of this species has been reported in 13 departments, of which Antioquia (4/8), Nariño (3/8), and Cundinamarca (2/8) have the greatest number of reports. There were only 3 studies with information at the municipality level; $L$. (L.) mexicana was reported in the municipalities of Gómez Plata in the department of Antioquia (12), Puerto López and Puerto Lleras in Meta (6), and Samaniego in Nariño (9).

Although $L$. (V.) guyanensis has a small geographical distribution (12 departments), this species has a greater number of circulation reports than $L$. (L.) mexicana. Leishmania ( $V$.) guyanensis was identified in 20 of the 86 studies. The frequency of reports is higher in the departments of Caquetá (7/20), Tolima (5/20), and Putumayo (4/20), which are located in the southwestern part of the country. In total, there are 13 municipalities that reported the circulation of $L$. (V.) guyanensis, distributed in the departments of Amazonas, Caquetá, Meta, Putumayo, Sucre, Tolima, and Valle del Cauca.

Leishmania (L.) infantum was identified in 15 studies in organisms from 11 departments, including Córdoba (6/14), Cundinamarca (5/14), and Sucre $(3 / 14)$, which have the highest number of reports of this species nationwide. The reports with detailed information of geographical origin come from 14 municipalities in 10 departments.

The 6 studies that report $L$. (L.) amazonensis indicate that the geographical distribution of this species is limited to the following 9 departments: Antioquia, Boyacá, Chocó, Meta, Nariño, Norte de Santander, Santander, Tolima, and Valle del Cauca. Of these, the department of Meta has the highest number of reports (4/6). In total, there are 12 municipalities in which $L$. (L.) amazonensis has been reported, distributed in the departments of Antioquia, Chocó, Meta, Nariño, Santander, Tolima, and Valle del Cauca.

To date, there are only two reports of $L$. $(V$.$) colombiensis in the country$ $(6,14)$. The samples came from patients from Río Grande and San Carlos municipalities of the department of Antioquia as well as from sand flies in the municipalities of El Carmen and San Vicente de Chucurí in Santander.

Leishmania $(V$.$) lainsoni and L$. $(V$.$) equatorensis were recently reported by$ Ramirez, et al., both identified from patients from the region of Antioquia (6).

Studies with less detailed information on the origin of the patients report the circulation of $L$. $(V$.) braziliensis and $L$. $(V$.) panamensis in the Amazon, Andean, Pacific and Orinoquia regions and $L$. ( $V$.) guyanensis in the Amazon and Andean regions (15). Likewise, the distributions of $L$. ( $V$.) panamensis and $L$. $(V$.) braziliensis were reported in the Amazonas, Atrato, Cauca, Magdalena, Mira, Orinoco, Patía, and San Juan river basins, whereas L. (V.) guyanensis was reported in the Amazonas river basin $(7,16)$. 


\section{Species typing techniques}

To date, the parasites of Leishmania spp. in Colombia have been identified using different methods, including isoenzyme pattern analysis, monoclonal antibody typing, and other molecular biology techniques. Multi-Locus Enzyme Electrophoresis (MLEE) has been the most widely used technique for the identification of Leishmania spp. parasites in Colombia $(4,17)$. MLEE is also used as a standard reference method for the confirmation of study findings $(5,18)$.

In recent years, techniques based on the amplification of DNA using PCR, such as Restriction Fragment Length Polymorphism (RFLP) (19), have been valuable in the identification of these parasites and in the analysis of nucleotide sequences $(6,10,20)$. In studies that use PCR for identification, the power of discrimination between species varies according to the molecular target. In reports in which species are identified to the genus, subgenus or species complex level, specific primers directed to kDNA minicircles were used $(21,22)$. Other molecular targets that allow the discrimination of Leishmania species are the $h s p 70$ gene $(18,19)$, the cytochrome b gene (Cyt b) $(6,20)$, the $7 S L R N A$ gene $(10,23)$ and the internal transcribed spacer 1 (ITS1) (18), and 16S rRNA (24).

\section{Clinical forms and their etiological agents}

Leishmania species in Colombia have been identified primarily from parasites isolated from lesions of cutaneous leishmaniasis. In total, there are 36 studies that used samples from patients with this clinical form. The incidences predominated, according to the number of reports, in the departments of Antioquia (10/36), Nariño (9/36), Meta (8/36), Tolima (8/36), Chocó (7/36), and Valle del Cauca (7/36).

The typing of species in the cutaneous leishmaniasis cases resulted in the identification of $L$. ( $V$.) panamensis as the most frequent causative agent of this clinical form. This was followed by $L$. ( $V$.) braziliensis, $L$. ( $V$.) guyanensis, $L$. (L.) mexicana, L. (L.) amazonensis and, with the same number of reports, L. (L.) infantum, L. (V.) colombiensis, L. (V.) lainsoni, and L. (V.) equatorensis.

Rodríguez, et al., in 1985, and Corredor, et al., in 1990, reported the identification of $L$. (L.) mexicana and $L$. $(L$.) amazonensis $(4,17)$ from patients with diffuse cutaneous leishmaniasis from the departments of Meta and Nariño.

To date, there are few studies that include the typing of Leishmania spp. from patients with mucosal leishmaniasis in Colombia (25-27). Cases of mucosal leishmaniasis were reported in the departments of Caquetá, Chocó, Cundinamarca, Meta, Nariño, Putumayo, and Valle del Cauca. Only L. (V.) braziliensis, $L$. $(V$.) panamensis, and $L$. ( $V$.) guyanensis have been identified as etiological agents of mucosal leishmaniasis.

Similarly, reports of species identified from patients with visceral leishmaniasis are scarce. Two papers have been published; the first, by Corredor, et al., does not indicate the geographical origin of the patient (4). The second study, by Mestra, et al., reported the development of visceral leishmaniasis in a patient with renal transplantation in Medellín (28). The genotyping of Leishmania species in these studies resulted in the identification of $L$. (L.) infantum (4) and $L$. (L.) mexicana (28). 


\section{Natural infection of sand flies}

Twenty-three studies were published between 1987 and 2018 that reported the natural infection by Leishmania spp. in 15 species of sand flies from 13 departments (table 2). Lutzomyia evansi, Lu. Iongipalpis, Lu. spinicrassa and $L u$. trapidoi were the most frequently reported species of sandflies. Of the 9 Leishmania species reported in the country, only $L$. (V.) panamensis, L. (V.) braziliensis, L. (V.) guyanensis, L. (L.) infantum, and $L$. $(V$.) colombiensis have been identified from sandflies (table 3 ).

Table 2. Reports of natural sand fly infection in Colombia

\begin{tabular}{|c|c|c|c|c|}
\hline Sand fly & Leishmania species & $\begin{array}{l}\text { Incrimination as vector } \\
\text { according to WHO }\end{array}$ & Department & Reference \\
\hline Lutzomyia antunesi & Leishmania spp. & No & Meta & (22) \\
\hline $\begin{array}{l}\text { Lu. cayennensis } \\
\text { cayennensis }\end{array}$ & $\begin{array}{l}\text { L. (L.) infantum } \\
\text { Leishmania spp. }\end{array}$ & No & $\begin{array}{l}\text { Sucre } \\
\text { Córdoba }\end{array}$ & $\begin{array}{l}(24) \\
(33)\end{array}$ \\
\hline \multirow[t]{2}{*}{ Lu. evansi } & L.(V.) braziliensis & No & $\begin{array}{l}\text { Bolívar } \\
\text { Sucre }\end{array}$ & $\begin{array}{l}\left({ }^{a}\right) \\
\left({ }^{b}\right)\end{array}$ \\
\hline & L. (L.) infantum & Yes & $\begin{array}{l}\text { Bolívar } \\
\text { Córdoba }\end{array}$ & $\begin{array}{c}(\stackrel{a}{)}) \\
(31-33)\end{array}$ \\
\hline Lu. flaviscutellata & Leishmania spp. & $\begin{array}{l}\text { Yes, for } L .(L .) \\
\text { amazonensis }\end{array}$ & Meta & (22) \\
\hline \multirow[t]{2}{*}{ Lu. gomezi } & L. (V.) panamensis & Yes & Boyacá & (36) \\
\hline & Leishmania spp. & Yes & $\begin{array}{l}\text { Córdoba } \\
\text { Meta }\end{array}$ & $\begin{array}{l}(33) \\
(22)\end{array}$ \\
\hline \multirow[t]{2}{*}{ Lu. hartmanni } & L. (V.) colombiensis & Yes & Santander & (14) \\
\hline & Leishmania spp. & Yes & Antioquia, Santander & (4) \\
\hline \multirow[t]{2}{*}{ Lu. longiflocosa } & L. (V.) guyanensis & Yes & Tolima & $(10)$ \\
\hline & Leishmania spp. & Yes & Norte de Santander & $\left({ }^{c}\right)$ \\
\hline \multirow[t]{3}{*}{ Lu. longipalpis } & L. (V.) panamensis & Yes & Cundinamarca & (6) \\
\hline & L. (L.) infantum & Yes & Cundinamarca & $(6,34,35)$ \\
\hline & Leishmania spp. & Yes & Santander & (37) \\
\hline \multirow[t]{2}{*}{ Lu. panamensis } & L. (V.) panamensis & Yes & Boyacá & (36) \\
\hline & Leishmania spp. & Yes & Meta & (22) \\
\hline Lu. shannoni & L. (V.) colombiensis & Yes & Santander & $(6)$ \\
\hline Lu. spinicrassa & L. (V.) braziliensis & Yes & $\begin{array}{l}\text { Antioquia, Meta } \\
\text { Norte de Santander }\end{array}$ & $\begin{array}{l}(18) \\
(30)\end{array}$ \\
\hline \multirow[t]{2}{*}{ Lu. trapidoi } & L. (V.) panamensis & Yes & $\begin{array}{l}\text { Antioquia, Meta, } \\
\text { Nariño, Santander } \\
\text { Tolima }\end{array}$ & $\begin{array}{c}(18) \\
(29,18) \\
(30)\end{array}$ \\
\hline & SubgenusViannia & Yes & Risaralda & $(11)$ \\
\hline Lu. umbratilis & L. (V.) guyanensis & Yes & $\begin{array}{c}\text { Amazonas } \\
\text { Boyacá, Santander }\end{array}$ & $\begin{array}{l}(30) \\
(18)\end{array}$ \\
\hline Lu. yuilli & L. (V.) panamensis & Yes & Boyacá & (36) \\
\hline $\begin{array}{l}\text { Warileya } \\
\text { rotundipennis }\end{array}$ & SubgenusViannia & No & Risaralda & (11) \\
\hline
\end{tabular}

${ }^{a}$ Romero-Ricardo L, Pérez-Doria A, Rodríguez J, Vergara J, Montesino A, Martínez L, et al. Lutzomyia evansi como vector permisivo de Leishmania braziliensis y Leishmania infantum en el departamento de Bolívar, Colombia. Memorias, XVI Congreso Colombiano de Parasitología y Medicina Tropical. Biomédica. 2015;35(Supl.4):185.

${ }^{b}$ Pérez A, Romero L, Martínez L, Rivero M, Bejarano E. Aislamiento y tipificación de una cepa de Leishmania (Viannia) braziliensis a partir de Lutzomyia evansi en el municipio de Colosó, Sucre. Memorias, XVI Congreso Colombiano de Parasitología y Medicina Tropical. Biomédica.2 015;35(Supl.4):112-3.

'Cárdenas R, Gutiérrez R, Cabrera O, Santamaría E, Parada H, Mendoza F, et al. Lutzomyia longiflocosa (Psychodidae, Phlebotominae) infectado naturalmente con Leishmania spp. en una región endémica de leishmaniasis tegumentaria americana. Memorias, XX Congreso Latinoamericano de Parasitología. Biomédica. 2011;31:270. 
Table 3. Reports of natural infection of animal hosts in Colombia

\begin{tabular}{|c|c|c|c|c|}
\hline Order & Reservoir & Leishmania species & Department & Reference \\
\hline \multirow[t]{6}{*}{ Rodentia } & Akodon spp. & $\begin{array}{l}\text { L. }(V .) \text { braziliensis } \\
\text { L. }(V .) \text { panamensis }\end{array}$ & $\begin{array}{l}\text { Norte de Santander } \\
\text { No data }\end{array}$ & $\begin{array}{l}(6) \\
(4)\end{array}$ \\
\hline & Coendou spp. & L. (V.) panamensis & No data & $(4)$ \\
\hline & Proechimys canicollis & L. (L.) infantum & Córdoba, Sucre & (38) \\
\hline & Rattus rattus & $\begin{array}{c}\text { L. (V.) panamensis } \\
\text { L. (V.) braziliensis complex }\end{array}$ & $\begin{array}{c}\text { No data } \\
\text { Valle del Cauca }\end{array}$ & $\begin{array}{r}(4) \\
(21)\end{array}$ \\
\hline & $\begin{array}{l}\text { Melanomys caliginosus } \\
\text { Microryzomys minutus }\end{array}$ & L. (V.) braziliensis complex & Valle del Cauca & $(21)$ \\
\hline & $\begin{array}{c}\text { Oecomystrinitatus } \\
\text { Sigmodon hispidus } \\
\text { Zygodontomys brunneus }\end{array}$ & Subgenus Viannia & Tolima & (39) \\
\hline \multirow[t]{3}{*}{ Didelphimorphia } & Metachirus nudicaudatus & L. (V.) panamensis & No data & $(4)$ \\
\hline & Didelphis marsupialis & L. (V.) panamensis & $\begin{array}{c}\text { No data } \\
\text { Boyacá } \\
\text { Chocó }\end{array}$ & $\begin{array}{r}(4) \\
(18) \\
\text { (a) }\end{array}$ \\
\hline & & L. (L.) infantum & Cundinamarca & $(4,6)$ \\
\hline \multirow[t]{16}{*}{ Carnivora } & & & $\begin{array}{c}\text { Córdoba, Sucre } \\
\text { Huila }\end{array}$ & $\begin{array}{r}(38) \\
(6)\end{array}$ \\
\hline & & L. (L.) mexicana & Antioquia, Santander & (18) \\
\hline & & L. (V.) braziliensis complex & Valle del Cauca & (21) \\
\hline & & Subgenus Viannia & Tolima & (39) \\
\hline & & Leishmania spp. & Bolívar & $\left({ }^{b}\right)$ \\
\hline & Micoureus demerarae & L. (V.) braziliensis complex & Valle del Cauca & $(21)$ \\
\hline & & L. (V.) panamensis & Huila & (6) \\
\hline & & L. (V.) braziliensis & $\begin{array}{c}\text { Valle del Cauca, } \\
\text { Nariño }\end{array}$ & $(40)$ \\
\hline & & & Tolima & (23) \\
\hline & & & Sucre & $\left({ }^{c}\right)$ \\
\hline & Canis familiaris & L. (V.) guyanensis & Meta & (41) \\
\hline & & & Tolima & $(23,36)$ \\
\hline & & & Sucre & $\left({ }^{c}\right)$ \\
\hline & & L. (L.) infantum & Cundinamarca & $(34,40)$ \\
\hline & & L. (L.) amazonensis & Tolima & (6) \\
\hline & & Leishmania spp. & Santander & $(d)$ \\
\hline Pilosa & Choloepus hoffmanni & L. (V.) panamensis & Valle del Cauca & $(42)$ \\
\hline Lagomorpha & Sylvilagus brasiliensis & L. (V.) braziliensis complex & Valle del Cauca & $(21)$ \\
\hline Perissodactyla & Equus asinus & L. (V.) braziliensis & No data & (4) \\
\hline
\end{tabular}

a Carrillo-Bonilla L, Vélez I, Vélez-Mira A, Boite M, Cupolillo E. Estudio ecoepidemiológico de Didelphis marsupialis y Canis familiaris como posibles reservorios de Leishmania panamensis en un ciclo selvático y periurbano de Colombia. Memorias, XVI Congreso Colombiano de Parasitología y Medicina Tropical. Biomédica. 2015: 35(Supl.4):158-9.

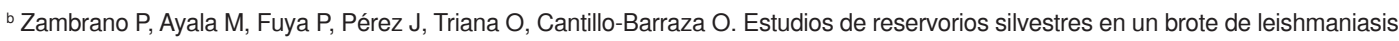
visceral urbana en Cartagena, departamento de Bolívar. Memorias, XX Congreso Latinoamericano de Parasitología. Biomédica. 2011;31:297.

${ }^{c}$ Rivero M, Rodríguez J, Meza E, Pérez-Doria A, Bejarano E. Primer hallazgo de Leishmania guyanensis y Leishmania braziliensis en perros asintomáticos del foco urbano de leishmaniasis del municipio de Ovejas, Sucre. Memorias, XVI Congreso Colombiano de Parasitología y Medicina Tropical, Biomédica. 2015;35(Supl.4):113.

d Márquez LL, Luna KP, Ángulo VM. Detección de infección por L. chagasi en una población canina de un foco de leishmaniosis visceral en Santander. Biomédica. 2003;23:115. 
Natural infection by L. (V.) panamensis, L. (V.) braziliensis, and L. (V.) guyanensis was detected primarily in $L u$. trapidoi $(18,29,30)$, Lu. spinicrassa $(4,18,30)$, and Lu. umbratilis $(4,10,18,30)$, respectively, whereas reports of natural infection by $L$. (L.) infantum occurred primarily in Lu. evansi (31-33) and $L$. longipalpis $(4,6,34,35)$. Infection with $L$. $(V$.) colombiensis in sand flies has only been reported in Lu. hartmani (14) and Lu. shannoni (6). Other species of sand flies in which a natural infection has been reported include Lu. longiflocosa by L. (V.) guyanensis (10), Lu. cayennensis by L. (L.) infantum (24), Warileya rotundipennis infected by parasites of the subgenus Viannia (11), and Lu. antunesi, identified at the genus level (22).

\section{Natural infection of animal hosts}

Since 1988, there have been 19 studies involving the isolation and identification of Leishmania species in animal hosts in Colombia. The natural infection has been described in 16 mammalian species, among which rodents and marsupials predominate. Nine mammalian species have only a single report of natural infection, whereas others, such as Canis familiaris and Didelphis marsupialis, have several reports of infection. The typing of Leishmania spp. in these animals led to the identification of $L$. $(V$.) panamensis, $L$. $(V$.) braziliensis, L. (V.) guyanensis, L. (L.) infantum, L. (L.) mexicana, and L. (L.) amazonensis. Of these, $L$. (V.) panamensis has been identified in 7 of the 16 species of mammals, including D. marsupialis, $C$. familiaris, Choloepus hoffmanni, Rattus rattus, and species of the genera Akodon and Coendou (table 3).

Leishmania $(V$.$) braziliensis and L$. (V.) guyanensis have been primarily isolated from $C$. familiaris. Of the species of subgenus Leishmania, $L$. $(L$.) infantum has the highest number of reports of natural infection in animal hosts, including $D$. marsupialis, $C$. familiaris and Proechimys canicollis (table 3 ).

\section{Discussion}

In this review, the 86 reports of Leishmania species in Colombia were compiled. Our goal was to characterize the geographical distribution of the species causing the different clinical forms and to map the natural infection of sand flies and other animal hosts. This information is valuable to health authorities because it allows the determination of transmission foci so that proper prevention measures may be established. Additionally, it provides information for the development of new research related to the Leishmania species in Colombia.

In addition, this review enabled us to describe the geographical distribution of the nine species circulating in 29 of the 32 departments of the country, expanding the area described by Ramírez, et al., which included information only from 23 departments (6).

One limitation of this work is that in most of the studies included the geographical origin of the samples analyzed was not specified in detail, which is why the described distribution is limited to the department. Thus, it is not possible to relate the location of the species to the geographical and climatological variations of the country. If future reports provide the exact location of the samples, such as village (vereda) and municipality, the precise geographical distribution of the parasite species could be updated.

The circulation of nine species of Leishmania makes Colombia one of the countries harboring the highest number of species. According to the established geographical distribution, the departments of Antioquia, Santander, and Meta have the highest number of circulating species and the 
highest number of species identification reports. These three departments accounted for $28.8 \%$ of the cases of leishmaniasis reported to the Instituto Nacional de Salud during the year 2016, of which Antioquia reported the second highest number of cases of cutaneous leishmaniasis, and Meta reported the highest number of cases of mucosal leishmaniasis (2).

Among the species identified as causing cutaneous leishmaniasis in the country, reports of $L$. (L.) infantum occurred in patients from the departments of Boyacá, Caldas, Cundinamarca, La Guajira, Meta, and Santander (6). This article does not describe the clinical characteristics of the cases and indicates only that the patients included had cutaneous leishmaniasis. Despite the close relationship between $L$. (L.) infantum and visceral leishmaniasis, cases of cutaneous leishmaniasis by this species have been previously reported in countries in Latin America, including Brazil (43) and Nicaragua (44).

Twenty-seven percent of the species identification reports were derived from sand fly studies. Natural infection was detected in 15 species, of which 11 are listed by WHO as confirmed vectors of leishmaniasis in Colombia (45). Among these, $L u$. evansi and $L u$. longipalpis are confirmed vectors of $L$. (L.) infantum and $L u$. trapidoi, Lu. spinicrassa and Lu. umbratilis are confirmed vectors of $L$. (V.) panamensis, $L$. (V.) braziliensis, and $L$. (V.) guyanensis, respectively (45). It is important to highlight the variety of sand fly species ( $L u$. trapidoi, Lu. gomezi, Lu. panamensis, Lu. yuilli and Lu. longipalpis) in which a natural infection by $L$. $(V$.) panamensis was detected, as this may be related to its wide distribution in the country.

The characterization of Leishmania spp. in mammals has been the least explored in the country. Of the animal species with reports of natural infection, many species of Leishmania have been identified in C. familiaris (table 3), which is listed as the main reservoir of $L$. $(L$.) infantum. Although there is evidence that this host plays a role in the transmission of parasites that cause cutaneous leishmaniasis, it is unknown whether $C$. familiaris acts as a reservoir or if it is an incidental host. Several species of mammals infected by Leishmania parasites have been reported in Colombia (table 3). Of the nine species of Leishmania circulating in Colombia, infection by $L$. (V.) colombiensis, L. (V.) lainsoni, and L. (V.) equatorensis have not been reported in animal hosts. As in Colombia, there are few reports of natural infection by these species in other Latin American countries.

This report gathered published information regarding the distribution of Leishmania spp. in Colombia from 1985 to 2017 and reveals that the available information is limited. Therefore, it is necessary to propose studies to identify the circulating species in endemic sites throughout the country that have not yet been reported and thus contribute to the control of the disease.

A possible strategy to update the species distribution map of Leishmania spp. in Colombia is to compile information on species typing and distribution in the country and thus create a consolidated map of available information. This would allow the areas in which there is no information on circulating species to be identified. It would be valuable to compare the distribution of the parasite species and the distribution of its vectors in the country (46).

\section{Acknowledgments}

We thank the Editorial Committee of the Centro Dermatológico Federico Lleras Acosta for its constructive comments that helped to improve the manuscript, and Eliana Cristancho, the librarian at the Center, for her recommendations for conducting the literature search. 


\section{References}

1. Alvar J, Vélez ID, Bern C, Herrero M, Desjeux P, Cano J, et al. Leishmaniasis worldwide and global estimates of its incidence. PloS ONE. 2012;7:e35671. https://doi.org/10.1371/journal.pone.0035671

2. Intituto Nacional de Salud. Boletín Epidemiológico Semanal. Diciembre 2016. Reporte No. 52. Fecha de consulta: 15 de marzo de 2017. Disponible en: http://www.ins. gov.co/buscador-eventos/BoletinEpidemiologico/2016\%20Bolet\%C3\%ADn\%20 epidemiol\%C3\%B3gico\%20semana\%2052\%20-.pdf

3. World Health Organization. Leishmaniasis in high-burden countries: An epidemiological update based on data reported in 2014. Wkly Epidemiol Rec. 2016;91:287-96.

4. Corredor A, Kreutzer RD, Tesh RB, Boshell J, Palau MT, Cáceres E, et al. Distribution and etiology of leishmaniasis in Colombia. Am J Trop Med Hyg. 1990;42:206-14. https://doi.org/10.4269/ajtmh.1990.42.206

5. Ovalle CE, Porras L, Rey M, Ríos M, Camargo YC. Distribución geográfica de especies de Leishmania aisladas de pacientes consultantes al Instituto Nacional de Dermatología Federico Lleras Acosta, ESE, 1995-2005. Biomédica. 2006;26:145-51. https://doi.org/10.7705/biomedica.v26i1.1508

6. Ramírez JD, Hernández C, León CM, Ayala MS, Flórez C, González C. Taxonomy, diversity, temporal and geographical distribution of cutaneous leishmaniasis in Colombia: A retrospective study. Sci Rep. 2016;6:28266. https://doi.org/10.1038/srep28266

7. Saravia NG, Weigle K, Navas C, Segura I, Valderrama L, Valencia AZ, et al. Heterogeneity, geographic distribution, and pathogenicity of serodemes of Leishmania viannia in Colombia. Am J Trop Med Hyg. 2002;66:738-44. https://doi.org/10.4269/ajtmh.2002.66.738

8. Patiño LH, Méndez C, Rodríguez O, Romero Y, Velandia D, Alvarado M, et al. Spatial distribution, Leishmania species and clinical traits of cutaneous leishmaniasis cases in the Colombian army. PLoS Negl Trop Dis. 2017;11:e0005876. https://doi.org/10.1371/journal.pntd.0005876

9. Arroyo C, Garzón J. Investigación de un foco de leishmaniasis cutánea en la zona andina del departamento de Nariño. Biomédica. 1995;16:25-31. https://doi.org/10.7705/biomedica.v16i1.887

10. Ferro C, Marín D, Góngora R, Carrasquilla MC, Trujillo JE, Rueda NK, et al. Phlebotomine vector ecology in the domestic transmission of American cutaneous leishmaniasis in Chaparral, Colombia. Am J Trop Med Hyg. 2011;85:847-56. https://doi.org/10.4269/ajtmh.2011.10-0560

11. Moreno M, Ferro C, Rosales-Chilama M, Rubiano L, Delgado M, Cossio A, et al. First report of Warileya rotundipennis (Psychodidae: Phlebotominae) naturally infected with Leishmania (Viannia) in a focus of cutaneous leishmaniasis in Colombia. Acta Tropica. 2015;148:191-6. https://doi.org/10.1016/j.actatropica.2015.04.017

12. Sierra D, Ochoa M, Calle JI, García G, Colorado D, Vélez ID. Leishmania (Leishmania) mexicana en el corregimiento de San Matías, municipio de Gómez Plata, Antioquia, Colombia. Biomédica. 2006;26:232-5. https://doi.org/10.7705/biomedica.v26i1.1517

13. Vélez ID, Carrillo LM, López L, Rodríguez E, Robledo SM.An epidemic outbreak of canine cutaneous leishmaniasis in Colombia caused by Leishmania braziliensis and Leishmania panamensis. Am J Trop Med Hyg. 2012;86:807-11. https://doi.org/10.4269/ajtmh.2012.11-0408

14. Kreutzer RD, Corredor A, Grimaldi G, Grogl M, Rowton ED, Young DG, et al. Characterization of Leishmania colombiensis Sp. N (Kinetoplastida: Trypanosomatidae), a new parasite infecting humans, animals, and phlebotomine sand flies in Colombia and Panama. Am J Trop Med Hyg. 1991;44:662-75. https://doi.org/10.4269/ajtmh.1991.44.662

15. Fernández OL, Díaz-Toro Y, Ovalle C, Valderrama L, Muvdi S, Rodríguez I, et al. Miltefosine and antimonial drug susceptibility of Leishmania Viannia species and populations in regions of high transmission in Colombia. PLoS Negl Trop Dis. 2014;8:e2871. https://doi.org/10.1371/journal.pntd.0002871

16. Saravia NG, Segura I, Holguín AF, Santrich C, Valderrama L, Ocampo C. Epidemiologic, genetic, and clinical associations among phenotypically distinct populations of Leishmania (Viannia) in Colombia. Am J Trop Med Hyg. 1998;59:86-94. https://doi.org/10.4269/ajtmh.1998.59.86

17. Rodríguez G, Corredor A, Cáceres E, Cassiano G, Arroyo C, Palau M, et al. Leishmaniasis difusa. Biomédica. 1985;5:95-111. https://doi.org/10.7705/biomedica.v5i3-4.1909 
18. Hernández C, Álvarez C, González C, Ayala MS, León CM, Ramírez JD. Identification of six New World Leishmania species through the implementation of a High-Resolution Melting (HRM) genotyping assay. Parasit Vectors. 2014;7:501. https://doi.org/10.1186/s13071-014-0501-y

19. Posada L, Vélez A, Acosta L, Cadena H, Agudelo D, Vélez I. Descripción de un foco endémico de leishmaniasis cutánea en Puerto Valdivia, Antioquia, Colombia. CES Salud Pública. 2014;5:3-10.

20. Martínez LP, Rebollo JA, Luna AL, Cochero S, Bejarano EE. Molecular identification of the parasites causing cutaneous leishmaniasis on the Caribbean coast of Colombia. Parasitol Res. 2010;106:647-52. https://doi.org/10.1007/s00436-009-1712-6

21. Alexander B, Lozano C, Barker DC, McCannb SHE, Adler GH. Detection of Leishmania (Viannia) braziliensis complex in wild mammals from Colombian coffee plantations by PCR and DNA hybridization. Acta Trop. 1998;69:41-50. https://doi.org/10.1016/S0001-706X(97)00114-9

22. Vásquez-Trujillo A, González-Reina AE, Góngora-Orjuela A, Prieto-Suárez E, Palomares JE, Buitrago-Álvarez LS. Seasonal variation and natural infection of Lutzomyia antunesi (Diptera: Psychodidae: Phlebotominae), an endemic species in the Orinoquia region of Colombia. Mem Inst Oswaldo Cruz. 2013;108:463-9. https://doi.org/10.1590/S0074-0276108042013011

23. Santaella J, Ocampo CB, Saravia NG, Méndez F, Góngora R, Gómez MA, et al. Leishmania (Viannia) infection in the domestic dog in Chaparral, Colombia. Am J Trop Med Hyg. 2011;84:674-80. https://doi.org/10.4269/ajtmh.2011.10-0159

24. Cochero S, Anaya Y, Díaz Y, Paternina M, Luna A, Paternina L, et al. Infección natural de Lutzomyia cayennensis cayennensis con parásitos tripanosomatídeos (Kinetoplastida: Trypanosomatidae) en Los Montes de María, Colombia. Rev Cubana Med Trop. 2007;59:35-9.

25. Santrich C, Segura I, Arias AL, Saravia NG. Mucosal disease caused by Leishmania braziliensis guyanensis. Am J Trop Med Hyg. 1990;42:51-5. https://doi.org/10.4269/ajtmh.1990.42.51

26. Saravia NG, Holguín AF, McMahon-Pratt D, D’Alessandro A. Mucocutaneous leishmaniasis in Colombia - Leishmania-braziliensis subspecies diversity. Am J Trop Med Hyg. 1985;34:714-20. https://doi.org/10.4269/ajtmh.1985.34.714

27. Weigle KA, Saravia NG, de Dávalos M, Moreno LH, D’Alessandro A. Leishmania braziliensis from the Pacific coast region of Colombia: Foci of transmission, clinical spectrum and isoenzyme phenotypes. Am J Trop Med Hyg. 1986;35:722-31. https://doi.org/10.4269/ajtmh.1986.35.722

28. Mestra L, López L, Robledo SM, Muskus CE, Nicholls RS, Vélez ID. Transfusiontransmitted visceral leishmaniasis caused by Leishmania (Leishmania) mexicana in an immunocompromised patient: A case report. Transfusion. 2011;51:1919-23. https://doi.org/10.1111/j.1537-2995.2011.03092.x

29. Travi BL, Montoya J, Solarte Y, Lozano L, Jaramillo C. Leishmaniasis in Colombia. I. Studies on the phlebotomine fauna associated with endemic foci in the Pacific Coast region. Am J Trop Med Hyg. 1988;39:261-6. https://doi.org/10.4269/ajtmh.1988.39.261

30. Young DG, Morales A, Kreutzer RD, Alexander JB, Corredor A, Tesh RB. Isolation of Leishmania-braziliensis (Kinetoplastida, Trypanosomatidae) from cryopreserved Colombian sand flies (Diptera, Psychodidae). J Med Entomol. 1987;24:587-9. https://doi.org/10.1093/jmedent/24.5.587

31. Travi BL, Montoya J, Gallego J, Jaramillo C, Llano R, Vélez ID. Bionomics of Lutzomyia evansi (Diptera: Psychodidae) vector of visceral leishmaniasis in northern Colombia. J Med Entomol. 1996;33:278-85. https://doi.org/10.1093/jmedent/33.3.278

32. Travi BL, Vélez ID, Brutus L, Segura I, Jaramillo C, Montoya J. Lutzomyia evansi, an alternate vector of Leishmania chagasi in a Colombian focus of visceral leishmaniasis. Trans R Soc Trop Med Hyg. 1990;84:676-7. https://doi.org/10.1016/0035-9203(90)90142-2

33. Vélez ID, Travi B, Gallego J, Palma G, Agudelo S, Montoya J, et al. Evaluación ecoepidemiológica de la leishmaniosis visceral en la comunidad indígena Zenú de San Andrés de Sotavento, Córdoba: primer paso para su control. Revista Colombiana de Entomología. 1995;21:111-22.

34. Corredor A, Gallego JF, Tesh RB, Morales A, de Carrasquilla CF, Young DG, et al. Epidemiology of visceral leishmaniasis in Colombia. Am J Trop Med Hyg. 1989;40:480-6. https://doi.org/10.4269/ajtmh.1989.40.480 
35. Ferro C, Morrison AC, Torres M, Pardo R, Wilson ML, Tesh RB. Age structure, blood-feeding behavior, and Leishmania chagasi infection in Lutzomyia longipalpis (Diptera: Psychodidae) at an endemic focus of visceral leishmaniasis in Colombia. J Med Entomol. 1995;32:618-29. https://doi.org/10.1093/jmedent/32.5.618

36. Santamaría E, Ponce N, Zipa Y, Ferro C. Presencia en el peridomicilio de vectores infectados con Leishmania (Viannia) panamensis en dos focos endémicos en el occidente de Boyacá, piedemonte del valle del Magdalena medio, Colombia. Biomédica. 2006;26:8294. https://doi.org/10.7705/biomedica.v26i1.1503

37. Flórez M, Martínez JP, Gutiérrez R, Luna KP, Serrano VH, Ferro C, et al. Lutzomyia longipalpis (Diptera: Psychodidae) en un foco suburbano de leishmaniosis visceral en el Cañón del Chicamocha en Santander, Colombia. Biomédica. 2006;26:109-20. https://doi.org/10.7705/biomedica.v26i1.1505

38. Travi BL, Osorio Y, Becerra MT, Adler GH. Dynamics of Leishmania chagasi infection in small mammals of the undisturbed and degraded tropical dry forests of northern Colombia. Trans R Soc Trop Med Hyg. 1998;92:275-8. https://doi.org/10.1016/S0035-9203(98)91009-4

39. Ocampo CB, Ferro MC, Cadena H, Góngora R, Pérez M, Valderrama-Ardila CH, et al. Environmental factors associated with American cutaneous leishmaniasis in a new Andean focus in Colombia. Trop Med Int Health. 2012;17:1309-17. https://doi.org/10.1111/j.1365-3156.2012.03065.x

40. Travi BL, Tabares CJ, Cadena H. Leishmania (Viannia) braziliensis infection in two Colombian dogs: A note on infectivity for sand flies and response to treatment. Biomédica. 2006;26:249-53. https://doi.org/10.7705/biomedica.v26i1.1520

41. Vásquez-Trujillo A, Gonzáles A, Góngora-Orjuela A, Cabrera O, Santamaría E, BuitragoÁlvarez L. Identificación de Leishmania (Viannia) guyanensis en caninos, en zona rural del municipio de Villavicencio, Meta, Colombia. Orinoquia. 2008;12:173-81.

42. Loyola EG, Alzate A, Sánchez A, González A. Epidemiology of a natural focus of Leishmaniabraziliensis in the pacific lowlands of Colombia. III. Natural infections in wild mammals. Trans R Soc Trop Med Hyg. 1988;82:406-7. https://doi.org/10.1016/0035-9203(88)90136-8

43. Castro LS, Franca Ade O, Ferreira Ede C, Hans Filho G, Higa Junior MG, Gontijo CM, et al. Leishmania infantum as a causative agent of cutaneous leishmaniasis in the state of Mato Grosso do Sul, Brazil. Rev Inst Med Trop Sao Paulo. 2016;58:23. https://doi.org/10.1590/S1678-9946201658023

44. Noyes H, Chance M, Ponce C, Ponce E, Maingon R. Leishmania chagasi: Genotypically similar parasites from Honduras cause both visceral and cutaneous leishmaniasis in humans. Exp Parasitol. 1997;85:264-73. https://doi.org/10.1006/expr.1996.4133

45. World Health Organization. Control of the Leishmaniases. Report of a meeting of the WHO Expert Committee on the control of Leishmaniases. Tech Rep Ser 949. Geneva: WHO; 2010. p. 1-186.

46. Ferro C, López M, Fuya P, Lugo L, Cordovez JM, González C. Spatial distribution of sand fly vectors and eco-epidemiology of cutaneous leishmaniasis transmission in Colombia. PloS One. 2015;10:e0139391. https://doi.org/10.1371/journal.pone.0139391 